\title{
Preliminary assessment of wealth creation in wood products' business in Ghana: The perspective of lumber and furniture production and implications for entrepreneurship
}

\author{
Peter Kessels Dadzie ${ }^{1, *}$, Martin Amoah², Stephen Lartey Tekpetey ${ }^{3}$ \\ ${ }^{1}$ Interior Architecture and Furniture Production Department, Kumasi Polytechnic, Kumasi, Ghana \\ ${ }^{2}$ Faculty of Technical and Vocational Education, University of Education of Winneba, Kumasi Campus, Kumasi, Ghana \\ ${ }^{3}$ Forest Products Development Division, CSIR-Forestry Research Institute of Ghana, Fumesua, Ghana \\ Email address: \\ pkkdadzie@yahoo.com (P. K. Dadzie), peter.kdadzie@kpoly.edu.gh (P. K. Dadzie), martamoah@yahoo.com (M. Amoah)
}

\section{To cite this article:}

Peter Kessels Dadzie, Martin Amoah, Stephen Lartey Tekpetey. Preliminary Assessment of Wealth Creation in Wood Products' Business in Ghana: The Perspective of Lumber and Furniture Production and Implications for Entrepreneurship. International Journal of Business and Economics Research. Vol. 3, No. 6, 2014, pp. 243-249. doi: 10.11648/j.ijber.20140306.15

\begin{abstract}
Export values of lumber appear lesser than those of garden furniture parts, but in Ghana, lumber entrepreneurs dominate the market. This study investigated the demand trends of wood species used for garden furniture and the Free-OnBoard (FOB) export values of their kiln-dried (KD) lumber and furniture. The study aimed at identifying and assessing the demand trends of wood species used for garden furniture production for exports, and making preliminary wealth creation assessment on converting lumber to garden furniture, all with the cardinal aim of arousing interests of entrepreneurs. The study covered a ten (10) year period from 2001 to 2010. Monthly export reports on wood products were reviewed to obtain relevant information for analyses. Findings indicated that, twenty-six Ghanaian hardwood species were demanded in the international garden furniture market, but Milicia excelsa (odum) wood species' garden furniture was the most preferred. However, Pericopsis elata (afromosia) wood species' furniture had the highest FOB value of $€ 3,300.788 / \mathrm{m}^{3}$ and Chrysophyllum albidum (akasaa) produced the highest additional income of $€ 2,203.09$ after value addition. After processing lumber to garden furniture, one is likely to obtain additional income averaging from $€ 188.599$ (emire- Terminalia ivorensis) to €2, 203.099 (akasaa). In conclusion, further processing lumber to garden furniture before exports may be economically viable, if labour cost and expenses are managed prudently. Entrepreneurs in Ghana should consider converting lumber to furniture for exports, as one good avenue for wealth creation and development. However, further studies to factor production costs into the analyses would be necessary to confirm the profitability in processing lumber to garden furniture.
\end{abstract}

Keywords: Furniture and Lumber Exports, Wood Species Demand Trends, Business and Entrepreneurship, Conversion of Lumber, Value-Addition to Wood

\section{Introduction}

Africa is endowed with some natural resources, including forest and its products, which are being exploited for development. Literature indicates that Africa used to have about 650 million hectares of forests which represented about $16.8 \%$ of the world's forest area, while Ghana had about 8.13 million hectares $\left(81,300 \mathrm{~km}^{2}\right)$ of high forest zone that contained over 300 timber species [1,2]

The various timber species in the forests are being used for the production of variety of wood-based products, including lumber, plywood, garden furniture etc., for both local and export markets [3, 4]. Garden furniture is basically furniture produced for outdoor use and they include chairs, tables, benches, sunloungers, swinging seats [5]. Though garden furniture can be produced from wood and other materials, the ones produced in Ghana for export are solely from wood. Unfortunately, the wood resource that serves as the raw material base for the timber-related industries, and for that matter garden furniture production is gradually depleting at a rate of $2 \%$ p.a [6]. This situation appears to have contributed 
to a reported annual revenue loss of some $€ 877,346.90$ to Ghana $[4,7]$ since the depleting trend is reported to have compelled some entrepreneurs in the wood related industries to either fold-up their businesses or operate below capacity all of which have had negative ripple effects on employment and the national economy[8]. In confirmation, it is reported that the forest heritage and its dependent industries, according to [9] are major contributors of Ghana's wealth as they contribute about 7 to $8 \%$ to the country's Gross Domestic Product (GDP) a decade ago but currently contribute only about $4 \%$ [6]. One way that this contribution could be largely improved is through value addition to the remaining timber stock by entrepreneurs in the sector.

It is important to note that the wealth or poverty of a country has direct link to the entrepreneurial nature of their economies since entrepreneurs play significant role in employment, economic growth and development [10]. Hence, entrepreneurs in the forest products industries could enhance the wealth contributed by the industry for national development and this can be done better through value addition to the depleting wood resource to create more wealth [2]. Value addition is an important issue for wealth creation in the wood processing sector, and garden furniture is seen to provide much better option than lumber in the wood products' export market mix [2]. But it appears that the entrepreneurs in the wood sector in Ghana are interested in lumber than furniture exports. It is reported that out of over 200 entrepreneurial firms in the wood processing sector, only two were producing garden furniture for exports by 2005[11]. One reason for this might be lack of information about the potential wealth that garden furniture could create than even kiln-dried lumber from the same wood species. However, available information on garden furniture exports from Ghana seems scattered and thus making it difficult for entrepreneurs to have a clear view of the attractive nature of the wealth creation capabilities of the venture. It is in this light that this research was conducted to showcase the potential wealth in the wood products industry, especially comparing lumber to furniture production for exports, so as to entice entrepreneurs, prospective entrepreneurs and their educators to consider garden furniture production and exports for much wealth creation towards individual and national development.

The results from this study would therefore be expected to unveil comparative information on lumber and garden furniture production and exports to aid and encourage entrepreneurs and prospective ones to add value to wood and possibly succeed in creating much wealth, since entrepreneurial activities and success are functions of the ability to identify opportunity and taking advantage of it [12]. It is also reported that entrepreneurship is a process through which individuals identify opportunities, allocate resources for the creation of values and wealth for development and growth [12]. However, education is also a key in developing entrepreneurial skills and attitudes. Hence, entrepreneurship education is important in the building of knowledge and skills of prospective entrepreneurs about entrepreneurship generally in all sectors of a country's economy [13], including the forestry and wood processing sectors. Thus entrepreneurship education that will incorporate forestry and forest products' industry studies will build knowledge and skills in the sector for personal and national development and growth.

According to [10], entrepreneurship has played significant roles in economic growth, innovation and competitiveness which have long term effects on job creation and poverty alleviation across the world. Additionally, [14] is of the view that, entrepreneurs see problems as opportunities and take actions to identity solutions to those problems, but entrepreneurial success is a function of the ability of an entrepreneur to see such opportunities for the creation of value and wealth. This view of [14] was reiterated by [13] who also indicated that the recognition of attractive opportunities for wealth creation is a complex process but a crucial ingredient for entrepreneurship success. But entrepreneurship education is what inculcates such skills and attitudes into people. Hence, entrepreneurship education is as necessary as the entrepreneurship itself. Therefore entrepreneurship success requires the services of entrepreneurial advisors or educators who have diverse experiences and knowledge to provide the needed tacit information that will create wealth in their fields of expertise [13]. As a result, making known the opportunities for wealth creation in the forestry and wood processing sector could be a form of education that might be of importance in tuning the minds of individual entrepreneurs onto value addition which could be more beneficial to them and the country at large.

In the light of the foregoing, it is important that entrepreneurs and prospective ones, including their educators, are provided with information in the forestry and wood processing sector, particularly kiln-dried lumber and furniture exports to: 1) identify the various wood species that exporters demand for garden furniture and their demand trends, and 2) make preliminary wealth creation (profitability) assessment of converting kiln-dried (KD) lumber to garden furniture for export.

\section{Methodology}

\subsection{Research Design}

The study was designed to cover a ten-year period from January 2001 to December 2010. Documents review and infactory study techniques were employed to collect relevant data for the study, while excel spreadsheet was used for computations and analysis of the data collected.

\subsection{Data Collection}

The research made use of secondary data from Ghana's Timber Industry Development Division (TIDD)-a national statutory institution in charge of timber industry's records, and both primary and secondary data from a local garden furniture firmthat produces over $90 \%$ of the furniture exported annually from the country $[11,15,16]$. Wood 
exports reports prepared by TIDD were reviewed to identify the various wood species being demanded in the export market for lumber and garden furniture while noting their values and volumes, over the period.

The In-factory study was done in the garden furniture firm to collect data on the recovery/efficiency rates relating to the conversion of kiln-dried lumber to garden furniture.

\subsection{Data Analysis}

The cumulative quantities or volumes $\left(\mathrm{m}^{3}\right)$ of garden furniture made from the various wood species demanded by exporters as well as their frequencies of demand were noted after which their means, for the period of study, were computed to represent the demand trend of the various species identified. The mean value/income from garden furniture exports (Free-On-Board, or FOB), in general and for each of the identified wood species, were obtained by dividing their cumulative values by their respective cumulative volumes exported. These mean values $/ \mathrm{m}^{3}$ were used as the export incomes/values after further processing lumber $(\mathrm{KD})$ to garden furniture, in general and for the specific wood species respectively, for profitability analyses. However, the mean FOB values of lumber, in general and for specific wood species determined were also used as lumber or raw material costs $/ \mathrm{m}^{3}$.

In determining mean recovery/efficiency rates of converting lumber to garden furniture, eleven (11) different wood species were sampled for the purpose (i.e. to find out how much lumber will be needed to produce $1 \mathrm{~m}^{3}$ of garden furniture) based on their frequencies of demand for garden furniture (i.e. those that obtained at least $50 \%$ appearances of the period of study) and the availability of work-in-progress on them. These species included Milicia excelsa (odum), Mixed Redwood, Khaya spp. (mahogany), Tectona grandis (teak), Piptadeniastrum africanum (dahoma), Albizia ferruginea (albizia), Chrysophyllum spp. (akasaa), Pericopsis elata (afromosia), Turraeanthus africanus (avodire), Guibourtia ehie (hyedua), and Terminalia ivorensis (emire).

During the in-factory studies, three replicates of three different garden furniture types made from each of the species were sampled to estimate the recovery rate of the species, using both primary and secondary data-from cutting specifications). Lumber Recovery Factor (LRF) formula; \{Tallied Output Lumber Volume (m3) / Input Log Volume (m3)\} x 100\% - [17] was modified and used for the computation of recovery rates of the sampled garden furniture units of individual wood species (using equation 1) after which the means for each wood species and the overall general mean rate for all the species were determined.

$$
\text { Recovery Rate of furniture }(R R)=\frac{\text { Output lumber volume }}{\text { Input tumber volume }} \times 100 \%
$$

Equation 2 was then used to determine the actual volume of lumber used to produce $1 \mathrm{~m}^{3}$ of garden furniture, both in general and for specific species. These determined how much mean volume of lumber per each species is needed to produce $1 \mathrm{~m}^{3}$ of garden furniture from the species and also how much lumber is generally needed to produce $1 \mathrm{~m}^{3}$ of garden furniture.

$$
\text { Raw Matcrial Volume }-\frac{\text { Total ftnished/planed lumber volume }}{\text { Recovery rate of wood species }} \times 100 \%
$$

Preliminary profitability of converting lumber to garden furniture was assessed using mean lumber volume of each species needed to produce $1 \mathrm{~m}^{3}$ of garden furniture and garden furniture values, relating to each species, obtained from the review of the export reports. The mean raw material volume (lumber volume needed to produce $1 \mathrm{~m}^{3}$ of furniture) obtained for each wood species was multiplied by the mean FOB value of the species' lumber. The resulting values were used as the raw material cost per each cubic metre $\left(\mathrm{m}^{3}\right)$ of garden furniture produced. These costs were subsequently deducted from the respective FOB values of each species' furniture to determine any value difference. The value differences obtained were then compared with the FOB values of $1 \mathrm{~m}^{3}$ of lumber of the respective wood species. The relationships of these value differences and the values of $1 \mathrm{~m}^{3}$ of the respective species' lumber were determined in percentages, to establish any rise or fall in value after the value addition process and to make any conclusions and recommendations.

\section{Results and Discussions}

\subsection{Demand Trend for Various Wood Species Used for Garden Furniture}

The study revealed that, there are a total of twenty-six wood species that customers demand for the production of garden furniture in Ghana (Figure1). However, fourteen of them are of higher demand (they had equal or more than $50 \%$ of the total number of appearances) in the international market. The other twelve species were not so frequently being demanded (they had below $50 \%$ of the total number of appearances).

From Figure 1, it was observed that the fourteen species in frequent demand were from Milicia excelsa (odum) to Guibourtia ehie (hyedua) whereas the less demanded twelve are from Cedrela to Rubber Wood, when all counting begin from the left end of the figure. Out of the frequently demanded species, odum, followed by Khaya spp. (mahogany) were prominent, as they appeared throughout the period, and obtained $48.149 \%$ and $21.943 \%$ (representing $6705.624 \mathrm{~m}^{3}$ and $3055.923 \mathrm{~m}^{3}$ ) respectively of garden furniture total volume of $13,926.842 \mathrm{~m}^{3}$ exported. However, among all the 26 wood species identified, Entrandrophragma cylindricum (sapele) was the least demanded wood species in the garden furniture market, as it had only one year's appearance and the least percentage volume of $0.007 \%$ representing a total of $1.022 \mathrm{~m}^{3}$ of garden furniture exported. These imply that, any entrepreneur in plantation forestry with the ultimate aim of producing garden furniture for exports should focus on those fourteen wood species that are being 
demanded most in the international market, should taste and other market conditions remain the same.

The results presented in Figure1, also appeared to confirm the assertion of [18] that teak from Africa, including Ghana, iroko and mahogany from Ghana are among the top durable species that are being demanded by garden furniture customers currently. According to [5], such wood species posses some special chemical or physical attributes that naturally make them resistant to rot and insect attacks, and for that matter, make them more preferred for outdoor furniture. These findings also support [17] and also [19] who found that, many of such wood species posses natural preservatives or extractives like essential oils, waxes and gums, amongst others, that provide barriers to easy deterioration and thereby making them better fit for garden furniture production.

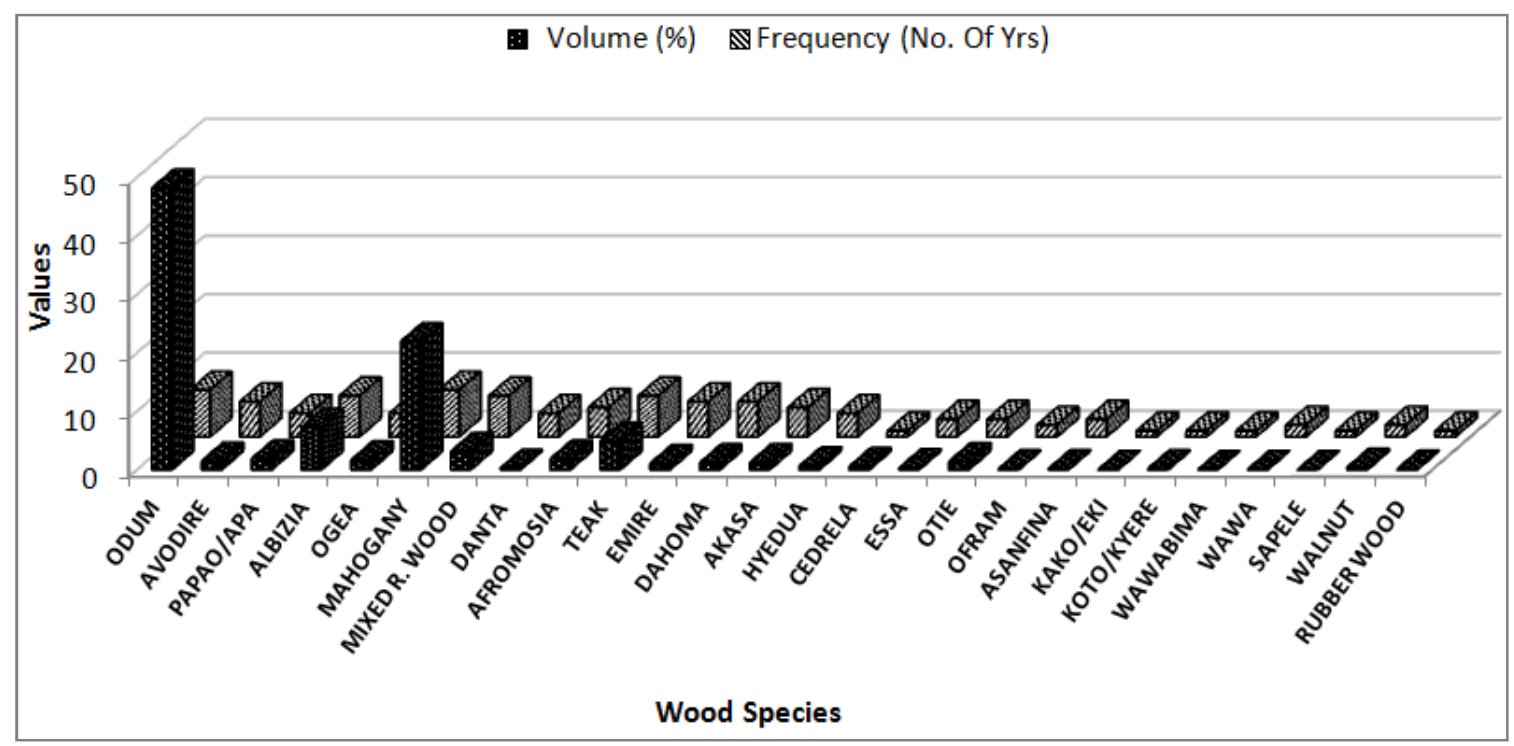

Figure 1. Demand trend of various wood species used for Furniture making. Note: Volumes are in percentagesof total $(13,926.842 \mathrm{~m} 3)$ exported within the study periodand Frequenciesare in number of years out of the 10 years). Source: TIDD Exports reports January 2001 to December 2010

Table 1. Recovery rates and export values of some wood species used for Furniture and Lumber production.

\begin{tabular}{|c|c|c|c|c|c|}
\hline Wood Species & $\begin{array}{l}\text { Lumber } \\
\text { Value } / \mathbf{M}^{3}(\boldsymbol{\epsilon})=\mathbf{A}\end{array}$ & $\begin{array}{l}\text { Recovery Rates or } \\
\text { conversion efficiencies } \\
(\%)\end{array}$ & $\begin{array}{l}\text { Value }(\epsilon) \text { of Volume to Produce } \\
1 \mathrm{~m}^{3} \text { of Furniture }=\text { B }\end{array}$ & $\begin{array}{l}\text { Value } / \mathbf{M}^{3}(\boldsymbol{\epsilon}) \text { of } \\
\text { Furniture }=\mathbf{C}\end{array}$ & $\begin{array}{l}\text { Additional income }(\epsilon) \\
\text { to be obtained }=\text { C-B }\end{array}$ \\
\hline Odum & 667.399 & 65.97 & $1,011.670$ & $2,468.994$ & $1,457.324$ \\
\hline Avodire & 397.759 & 51.60 & 770.851 & $1,657.717$ & 886.866 \\
\hline Albizia & 396.268 & 57.23 & 692.413 & $1,546.394$ & 853.981 \\
\hline Mahogany & 633.010 & 63.78 & 992.490 & $1,815.009$ & 822.519 \\
\hline Mixed redwood & 322.885 & 60.90 & 530.189 & $1,774.874$ & $1,244.685$ \\
\hline Afromosia & 868.997 & 55.87 & $1,555.391$ & $3,300.788$ & $1,745.397$ \\
\hline Teak & 545.436 & 56.10 & 973.819 & $2,785.153$ & $1,811.334$ \\
\hline Emire & 409.666 & 55.28 & 741.075 & 929.674 & 188.599 \\
\hline Dahoma & 315.984 & 57.35 & 550.975 & $1,189.973$ & 638.998 \\
\hline Akasaa & 499.951 & 61.69 & 810.425 & $3,013.524$ & $2,203.099$ \\
\hline Hyedua & 643.434 & 63.97 & $1,005.837$ & $2,315.339$ & $1,309.502$ \\
\hline Papao/Apa & 588.509 & 59.07 & 998.291 & $1,281.055$ & 282.764 \\
\hline Ogea & 436.953 & 59.07 & 739.721 & $2,413.895$ & $1,674.174$ \\
\hline Danta & 409.120 & 59.07 & 692.602 & $2,261.301$ & $1,568.699$ \\
\hline
\end{tabular}

Source: TIDD's Export Reports of January 2001 to December 2010 and field experiment from a local garden furniture firm.

\subsection{Preliminary Assessment of the Wealth Creation Ability in Converting Kiln-Dried (KD) Lumber to Garden Furniture}

\subsubsection{General Average Recovery Rate, Volume and FOB Values $/ \mathrm{m}^{3}$ of Lumber and Garden Furniture}

Findings revealed that, the annual average volume of exported lumber (KD) was as much as $111,735.990 \mathrm{~m}^{3}$ whereas that of garden furniture was only $1,740.851 \mathrm{~m}^{3}$. However, the annual average value $/ \mathrm{m}^{3}$ of kiln-dried lumber was $€ 373.860$ while that of garden furniture was as high as $€ 2,085.010$ and representing value difference of $€ 1,711.150$ equivalent to $457.700 \%$ value increase when lumber is converted into garden furniture for exports.

Meanwhile results from the in-factory study revealed that, the general average recovery rate of converting kiln dried lumber to garden furniture is $59.07 \%$, implying that, $1 \mathrm{~m}^{3}$ of garden furniture would generally be produced from about $1.693 \mathrm{~m}^{3}$ of lumber (KD). Hence the raw material (lumber) cost of producing $1 \mathrm{~m}^{3}$ of garden furniture should be 
calculated using $1.693 \mathrm{~m}^{3}$ and not $1 \mathrm{~m}^{3}$. This means that, to produce $1 \mathrm{~m}^{3}$ of garden furniture, the FOB value of the volume of lumber needed is about €632.945 (€373.860 x $\left.1.693 \mathrm{~m}^{3}\right)$. Hence, when the recovery rate is factored into the analyses, the raw material cost increases and reduces the value difference between $1 \mathrm{~m}^{3}$ of lumber and $1 \mathrm{~m}^{3}$ of furniture to $€ 1,452.065$ representing $388.398 \%$ increase. This is still a substantial increase which can be used to cater for labour and other cost that will be incurred on the value addition process and also make adequate profit to create wealth $[11,14,15$, 20-24].

\subsubsection{Recovery rate and Preliminary Profitability Analysis of Converting Individual Species' Lumber (KD) to Garden Furniture}

Figure 2, Table 1 and Figure 3 respectively show lumber and furniture values $/ \mathrm{m}^{3}$, preliminary profitability analyses and percentage additional incomes from sampled wood species. From Figure 2, it could be observed that garden furniture exhibited higher values $/ \mathrm{m}^{3}$ than kiln-dried lumber produced from the same species.

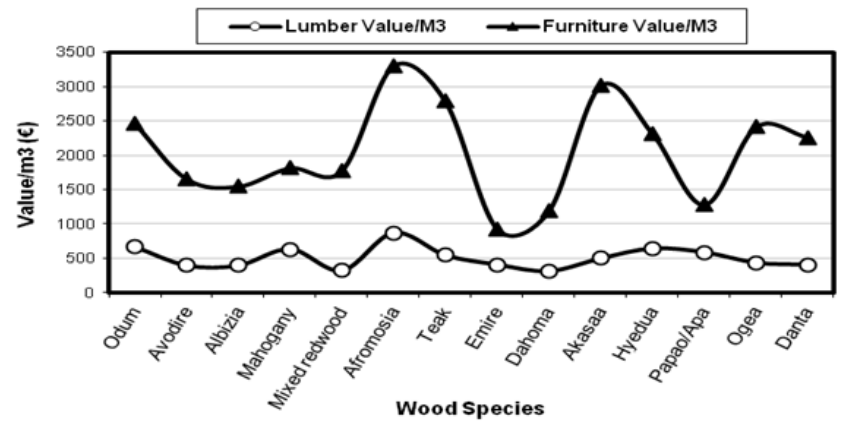

Figure 2. Kiln-dried lumber and garden furniture values $/ m^{3}$ ( $€$ ) for some individual wood species.

However, among the sampled species, Pericopsis elata (afromosia) exhibited the highest value for both lumber $\left(€ 868.997 / \mathrm{m}^{3}\right)$ and garden furniture $\left(€ 3,300.79 / \mathrm{m}^{3}\right)$ whereas Piptadeniastrum africanum (dahoma) had the lowest lumber value with Terminalia ivorensis (emire) exhibiting the lowest garden furniture value of $€ 929.67 / \mathrm{m}^{3}$ (Figure 2).

From Table 1, the efficiency/recovery rates showed that Milicia excelsa (odum) exhibited the highest value of $65.97 \%$ followed by Guibourtia ehie (hyedua), while Turraeanthus africanus (avodire) had the lowest of $51.60 \%$. These mean that $1.516 \mathrm{~m}^{3}$ of odum lumber and $1.938 \mathrm{~m}^{3}$ of avodire lumber would be needed for the production of $1 \mathrm{~m}^{3}$ of garden furniture respectively from those species. For papao/apa, ogea and danta, the general average recovery rate was used in their profitability analyses since no data on them was available.

The high recovery rate of odum reported in Table 1 could be attributed to the fact that it is a species of very good durability, fungus resistance, very minimal insect infestation, best opening face and reasonably termite-resistant. Moreover, the low rate for avodire may also be due to its low durability and high susceptibility to fungal and insect attack [25]. It is also documented that recovery rate or yield in the timber industry is affected by factors like end-use requirements, personnel competencies, accuracies of machinery, sawing accuracy, and both natural and artificial wood defects [26] while human errors account for greater losses than all factors because; the accuracy of operation at any point in the production line depends on the level of accurate decisions made by earlier operator(s) and subsequent ones [27]. It is therefore imperative that, potential entrepreneurs take cognisance of these factors that are likely to affect the efficiencies of the conversion process and avail themselves of education in those areas. Again, entrepreneurship education in the wood processing industry should also lay a lot of emphases on efficiency or recovery rate in order to create awareness on them to minimise waste and consequent loss of income.

Based on values $/ \mathrm{m}^{3}$ of both lumber and garden furniture, and recovery rates of the individual wood species, the preliminary additional incomes or profits $(€)$ (Table 1) translates into the percentage increases in values (Figure 3) when compared to the values $/ \mathrm{m}^{3}$ of lumber made from same species.

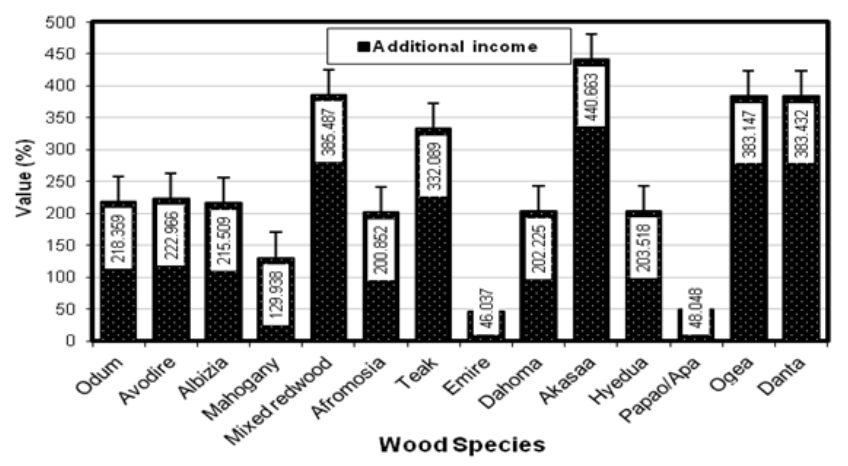

Figure 3. Percentage increases in value upon converting kiln-dried lumber to garden furniture from same wood species.

From Table 1 and Figure 3, akasaa garden furniture exhibited the highest additional income level of $€ 2,203.099$ followed by teak which had $€ 1,811.334$ which respectively represents $440.663 \%$ and $332.089 \%$ value increases in relation to the value of their kiln-dried lumber. Also,emire wood species had the lowest additional income of about $€ 188.599$ representing $46.370 \%$ compared to the value that one would have obtained from exports of the species' kilndried lumber.

On the whole, it could be deduced from Table 1and Figure 3 that by further processing lumber (KD) of various species to garden furniture, an entrepreneur is likely to accrue additional incomes $/ \mathrm{m}^{3}$ in the range of $€ 188.599$ to $€ 2,203.099$ representing $46.37 \%$ and $440.663 \%$ respectively when compared with the income to have been obtained from selling the wood in the lumber form (i.e. at the split offpoint). However, it is important to note that, these additional incomes will be realized after incurring additional costs (expenditures) in the value addition process in terms of cost of other materials, additional labour and additional expenses. 
In reference to these costs, the entrepreneur should ensure therefore that all such costs on each cubic metre $\left(\mathrm{M}^{3}\right)$ of furniture produced from a particular wood species do not exceed these found likely additional incomes/profit ranges, if wealth or profit is to be created or achieved.

It is however worthy of note that despite these additional incomes/profits, the number of garden furniture exporting companies in Ghana has decreased drastically by 2009 [11, $15,16,20-24,28,29]$. This worrying situation which has largely been attributed to shortages of timber raw materials owing to depletion of the forests needs to be dealt with. And one probable and immediate way to create wealth from the remaining timber stock is through value addition. Nonetheless, since entrepreneurs are a group of persons that see problems as opportunities and take action to identify solutions for wealth creation [14], entrepreneurs in Ghana and elsewhere should see the problem of dwindling timber resources as an opportunity to convince all stakeholders to grant them every possible incentive to go into value-added products manufacturing like garden furniture. Moreover, in the long term, educational curriculum or system that will produce entrepreneurs in the forestry and wood processing sectors of the economy could also be a solution and breakthrough for the value addition and replenishment of depleted forest resources. Therefore curriculum of Africa's educational systems should incorporate entrepreneurship education, especially in the area of value addition to wood resources, since according to [30], in recent years, the promotion of entrepreneurship education is seen as a revolution to solving numerous economic and social challenges facing developing countries. And what is happening in the forestry and wood products manufacturing sectors in Ghana is no exception.

\section{Conclusions and Recommendations}

This study sought to identify and assess the demand trends of the wood species used for garden furniture production in Ghana for the export market, and made preliminary assessment of the potential wealth to be created when entrepreneurs should convert lumber to garden furniture before exports.

The study has established that there are about twenty-six Ghanaian hardwood species in demanded for garden furniture in the export market, but fourteen of such species are mostly demanded. The level of their demand may be influenced by durability and beauty, which subsequently influence taste and desire of customers.

The preliminary additional income ranging from $46.037 \%$ for emire to $440.663 \%$ for akasaa indicates that further processing lumber to garden furniture for exports offers a more attractive and enticing opportunity for wealth creation. This implies that if entrepreneurs are able to manage costs of labour and other expenses prudently, much profit or wealth could be created when value is added to lumber by further processing it to garden furniture. Moreover, efficiency/recovery rate can also affect raw material cost greatly in furniture production and thus entrepreneurs should device means of minimizing waste of lumber/wood during garden furniture manufacturing.

It is therefore recommended that, entrepreneurs interested in plantation forestry for garden furniture production and exports should concentrate on the fourteen garden furniture wood species. Also, entrepreneurship education planners should consider incorporating into entrepreneurship studies, aspects of technical disciplines like forestry and forest products technology, with much emphasis on garden furniture production for exports, as one of its policy directions for wealth creation and development.

Also, further studies that factor the total expenditure incurred in producing garden furniture from kiln-dried lumber in general and for the individual species would be necessary to confirm the results on additional incomes or profits found in this present study on garden furniture production for export.

\section{References}

[1] Forestry Department, (1995) Timber Yield from the Forests Resources of Ghana-An Analysis on Sustainable Forest Management. Unpublished. pp. 31-33.

[2] Asumadu, K. (1997) Forest Resources-Declining Nature, Competitiveness in International Trade, Policy and Institutional Changes to promote investment, in AFORNET Policy Brief No. 8, Wood Based Industries in Sub-Saharan Africa. pp. 12-18.

[3] Pleydell, G. (1994) The Tropical Timbers of Ghana, Timber Export Development Board, Takoradi. Ghana. pp 4-86.

[4] Pleydell, G., Spooner T. and Moor, L. (2002) Ghana's Forests Reporting Progress, Ghana Forestry Commission and TIDD. Ghana. pp. 4-11.

[5] Plow, and Heart Inc., (2006) Furniture Buying Guide. www.plowhearth.com/ Outlet Store. Asp. (Accessed April 2006).

[6] Ministry of Lands and Natural Resources-MLNR. (2012) Ghana-Forest Investment Program (FIP) Plan. Draft-March 2012. Retrieved, November, 2012, from

[7] http://www.fcghana.org/assets/file/Programmes/Forest_Invest ment_Plan_fip/Ghana $\%$.

[8] World Bank, (1988). In Murray, C. H. (1993). The Challenge of Sustainable Forest Management - What Future for World's Forest. FAO of the UN Commonwealth Forestry Review. pp. 34-60.

[9] Antwi L B. (1999) What We Have; Our Forest Heritage. In Owusu JGK, Abeney EA,

[10] Frimpong E A, editors. Proceedings Workshop for Media Personnel on Forestry and Wildlife Reporting, Department of Silviculture and Forest Management-FRNR-KNUST, Kumasi, Ghana; P. 24-29.

[11] Zaney G.D. (2011). Developing Commercial Forestry and the role of the Fund Management Board, The Ghanaian Times, Thursday, May 192011 pp.9. 
[12] Landes, D. (1998). The Wealth and Poverty of Nations, New York. www.Norton. (Accessed Sept. 2011).

[13] TIDD. (2005) Exporters Performance/Moving Species/Direction of Trade-Lumber (KD) and Furniture Parts; Wood Products Export Report, December, Data Processing Section, Takoradi. Ghana. pp. 3-54.

[14] Watson, G. (2010). Entrepreneurship, Education, and Ethics; Definition and Current Research Entrepreneurship. www.gregwatson.com/entrepreneurship-definition/research. (Accessed, October 2011)

[15] Martinez, A. C.; Levie, J.; Kelley, D. J.; Sæmundsson, R. J.; Schøtt, T., (2010) A Global Perspective on Entrepreneurship Education and Training; Global Entrepreneurship Monitor (GEM) Special Report of 2008. pp. 1142.www.gemconsortium.org. (Accessed, October 2011).

[16] Greg W. (2010) Entrepreneurship Education and Ethics. httpp//www.gregWatson.com/entrepreneurship-definitions. (Accessed, Sept. 2011).

[17] TIDD. (2003) Exporters Performance/Moving Species/Direction of Trade-Lumber (KD) and Furniture Parts; Wood Products Export Report, December, Data Processing Section, Takoradi. Ghana. pp. 1-36.

[18] TIDD. (2004) Exporters Performance/Moving Species/Direction of Trade-Lumber (KD) and Furniture Parts; Wood Products Export Report, December, Data Processing Section, Takoradi. Ghana. pp. 2-42.

[19] Haygreen, J. G. and Bowyer J. L., (1996). Forest Products and Wood Science-An Introduction, $3^{\text {rd }}$ Edition, IOWA State University Press, Ames.U.S.A. pp. 155-276.

[20] Alexander R. Ltd., (2005) Fine Quality Traditional Garden Furniture, Alexander Rose Ltd., WestSussex. U.K. pp 1-5.

[21] Eero, S. (1993) Wood Chemistry Fundamentals and Applications, $2^{\text {nd }}$ Edition, Academic Press, New York. U.S.A. pp. $90-108$.

[22] TIDD.- Timber Industries Development Division (2001). Exporters Performance/Moving Species/Direction of TradeLumber (KD) and Furniture Parts; Wood Products Export Report, December, Data Processing Section, Takoradi. Ghana. pp. 2-33.

[23] TIDD. (2002) Exporters Performance/Moving
Species/Direction of Trade-Lumber (KD) and Furniture Parts; Wood Products Export Report, December, Data Processing Section, Takoradi. Ghana. pp. 1-36.

[24] TIDD. (2006) Exporters Performance/Moving Species/Direction of Trade-Lumber (KD) and Furniture Parts; Wood Products Export Report, December, Data Processing Section, Takoradi. Ghana. pp. 1-36.

[25] TIDD. (2007) Exporters Performance/Moving Species/Direction of Trade-Lumber (KD) and Furniture Parts; Wood Products Export Report, December, Data Processing Section, Takoradi. Ghana. pp. 1-31.

[26] TIDD. (2008). Exporters Performance/Moving Species/Direction of Trade-Lumber (KD) and Furniture Parts; Wood Products Export Report, December, Data Processing Section, Takoradi. Ghana. pp. 2-41.

[27] GDV. -Gesamtverb and der Deutschen Versicherungswirtschafte. V, Berlin (2005) Properties of Wood Species. www.tis-gdv.de/tis_e/inhalt.html. (Accessed October 2005).

[28] White, V. (1974) Modern Sawmilling Techniques, Vol. 3, Miller Freeman, San Francisco. U.S.A. pp. 320-323.

[29] Herbert, Lambert G. (1974). Modern Sawmilling Technique Vol. 4, Proceedings of the $4^{\text {th }}$ Sawmilling Clinic. Anew Orleans, Louisiana. p. 296.

[30] TIDD. (2009) Exporters Performance/Moving Species/Direction of Trade-Lumber (KD) and Furniture Parts; Wood Products Export Report, December, Data Processing Section, Takoradi. Ghana. pp. 1-22.

[31] TIDD. (2010). Exporters Performance/Moving Species/Direction of Trade-Lumber (KD) and Furniture Parts; Wood Products Export Report, December, Data Processing Section, Takoradi. Ghana. pp. 1-30.

[32] Ministries of Trade and Industry, Labour and Social Welfare, Education, Science and Technology (unpublished). 'See Opportunities and make them Work!' A National Strategy for Entrepreneurship Education and Training, Provisional Institutions of Self-Government,

[33] Government of Kosovo.www.mashtgov.net/advCms/documents/(Accessed, October. 2011). 